\title{
WADAH PERTUKARAN PENGALAMAN RUANG DI MENTENG
}

\author{
Muhammad Yumna Helmy ${ }^{1)}$, Fermanto Lianto ${ }^{2)}$ \\ ${ }^{1)}$ Program Studi S1 Arsitektur, Fakultas Teknik, Universitas Tarumanagara, helmyyumna@gmail.com \\ 2)Program Studi S1 Arsitektur, Fakultas Teknik, Universitas Tarumanagara, fermantol@ft.untar.ac.id

\begin{abstract}
Abstrak
Kejenuhan akan rutinitas serta aktivitas harian yang serba padat mwarnai kehidupan di perkotaan, hal ini yang mengakibatkan tingkat rasio kemungkinan stress di kota-kota besar seperti Jakarta lumayan besar. Ditengah rutinitas hidup, banyak orang yang mencari hiburan maupun rekreasi untuk semata-mata melepas kepenatan dari aktivitas seharihari. Kedudukan ruang interaksi bagi warga Menteng sangat berarti, tidak hanya menyangkut tata ruang fisik lingkungan, ruang publik juga mengemban peranan dan arti sosial serta kultural yang sangat besar. Tetapi, perkembangan kota yang cepat mengakibatkan tuntutan kebutuhan lahan perkotaan kian bertambah. Privatisasi lahan baik secara individual ataupun badan hukum/lembaga telah menimbulkan eksistensi ruang publik kian terpinggirkan. Apalagi di permukiman-permukiman padat penghuni, warga sudah tidak mempunyai lagi ruang publik yang mencukupi untuk mewadahi aktivitas mereka. Penduduk tidak lagi mempunyai ruang bersama buat silih korelasi, komunikasi antar warga, anak-anak tidak lagi mempunyai tempat bermain yang nyaman di ruang luar, sehingga budaya kebersamaan serta toleransi terus menjadi terkikis. Dengan hadirnya wadah ini di tengah tengah kesibukan dan kebutuhan masyarakat sekitar, diharapkan dapat meningkatkan sikap toleransi antar masyarkat dan menghasilkan kegiatan kegiatan yang baru yang dapat meningkatkan produktivitas dan toleransi antar warga sekitar yang berdampak luas terhadap kawasan sekitar.
\end{abstract}

Kata kunci: interaksi; pengalaman ruang; sosialisasi; third place; wadah pertukaran

\begin{abstract}
The urban life is not separated from the saturation of the daily routine and activities, which causes the level of stress ratio in major cities such as Jakarta is quite high. During the demands and routine of life, many people looking for entertainment or recreation to take off the fatigue of daily activities. The role of interaction room for the people of Menteng is very important, in addition to the physical layout of the environment, the public space also bears the function and significance of social and cultural very high. However, the rapid growth of the city's demand for urban land demands increased. The privatization of land, either individually, as well as legal entities/institutions, has caused the existence of public space to be increasingly affected. Even in the crowded settlements of residents, people have no more public space adequate to host their activities. People no longer have a shared space to interact with each other, communication between citizens; children no longer have a place to play in the outside space, so that the culture of togetherness and tolerance is increasingly misguided. With the presence of this container during busy and the needs of the surrounding community, it is expected to increase the attitude of tolerance between the community and produce new activities that can increase the productivity and tolerance between the surrounding residents who have a wide impact on the region.
\end{abstract}

Keywords: exchange place; interaction; socialization; space experience; third place 


\section{PENDAHULUAN}

Kota Jakarta, selaku ibukota mempunyai perkembangan yang cepat dan pesat. Dengan banyaknya pembangunan dan perkembangan di banyak tempat, perkembangan ini membuat Jakarta sebagai pusat dari semua kegiatan pemerintahan, bisnis sosial, serta hiburan di Indonesia. Masyarakat dari luar daerah mencari kehidupan yang lebih baik di Jakarta dan dalam skala besar, masyarakat lokal dan daerah berlomba lomba untuk mendapatkan kehidupan tersebut. Dengan perkembangan penduduk yang bertingkat hingga sekitar 222.738 orang (4\%) per tahunnya (Dinas Kependudukan dan Catatan Sipil DKI Jakarta, 2005), maka semakin sedikit pula ketersediaan lahan di Jakarta, dan menyebabkan naiknya harga tanah di ibukota.

Pada dasarnya, manusia diciptakan sebagai makhluk yang memiliki kemampuan berinteraksi dan bertindak sebagai makhluk individu maupun sosial. Sebagai individu, manusia dapat melakukan komunikasi secara pribadi berdasar 3 poin utama, yaitu persepsi terhadap diri pribadi, kesadaran pribadi, dan pengungkapan diri. Hal tersebut menjadi wajar karena adanya unsur karakteristik dan jati diri yang berbeda di setiap diri manusia. Namun dalam perjalanannya, manusia tidak dapat terus-menerus berperan sebagai individu, manusia sebagai makhluk sosial juga membutuhkan ruang tersendiri sebagai bagian dari proses perkembangan.

Berdasarkan pengamatan di lapangan, Menteng merupakan daerah pemerintahan dan perkantoran dengan tingkat mobilitas yang tinggi pada waktu tertentu. Volume kendaraan yang tidak dapat di prediksi membuat daerah tersebut menjadi daerah yang padat akan kendaraan pribadi maupun kendaraan umum.

Di kawasan menteng, para pekerja rata rata mempunyai pekerjaan yang berat dan juga harus menghadapi di waktu berangkat dan juga pulang kerja. Berdasarkan pengamatan di lapangan dan bertanya pada masyarakat di sekitar tapak, para pekerja di daerah Menteng memiliki tingkat kesabaran yang tinggi dikarenakan oleh kegiatan yang merek ahadapi sehari hari. Dari menghadapi kemacetan, menghadapi pekerjaan, tekanan bekerja dan lainnya, membuat masyarakat di daerah Menteng memiliki mental dan kesabaran yang tinggi. Namun, dikarenakan hal hal yang dihadapi oleh para pekerja diatas, hal tersebut menyebabkan para pekerja menjadi dull,atau tumpul dalam bersosialisasi dan berinteraksi kepada orang lain, dikarenakan tidak adanya fasilitas atau tempat di daerah tersebut yang mempertemukan masyarakat sekitar maupun diluar wilayah tersebut untuk berinteraksi selain berinteraksi pun dapat menjalin relasi.

Selain kelebihan dan kekurangan diatas, Kecamatan Menteng sendiri mempunyai kekhasan yang terkenal akan pusat jual beli barang antik yang sampai sekarang masih menjadi pusat perhatian dari bergabai kalangan. Barang antik yang perjualbelikan, dari barang barang yang terkenal akan bahan dan fungsi sehingga barang barang yang menarik bagi para kolektor dari dalam maupun luar kota.

Kedudukan ruang interaksi bagi penduduk Menteng sangat penting, tidak hanya menyangkut tata ruang fisik lingkungan, ruang publik pula mengemban guna serta arti sosial dan kultural yang sangat besar. Tetapi, perkembangan kota yang cepat menyebabkan tuntutan kebutuhan lahan perkotaan kian bertambah. Privatisasi lahan baik secara individual ataupun badan hukum telah menyebabkan eksistensi ruang publik kian terpinggirkan. Terlebih lagi di permukimanpermukiman padat penghuni, penduduk sudah tidak mempunyai lagi ruang publik yang mencukupi untuk mewadahi kegiatan mereka. Di isi lain, miskinnya ruang publik yang dapat menampung bermacam kegiatan bersama dikhawatirkan terbentuknya bermacam perkara sosial kemasyarakatan selaku akibat dari minimnya kebersamaan serta sosialisasi antarwarga. Warga tidak lagi mempunyai ruang bersama untuk silih korelasi, komunikasi antar penduduk, anak-anak tidak lagi mempunyai tempat bermain yang nyaman di ruang luar, sehingga budaya kebersamaan serta toleransi terus menjadi terkikis. 


\section{KAJIAN LITERATUR}

\section{Open Architecture}

Open Architecture merupakan sistem terbuka yang berfungsi sebagai ruang antara bukan sebagai tempat untuk tinggal (home) dan tempat untuk bekerja (work). Permasalahan pada kota-kota besar biasanya memiliki ciri masyarakat yang individualistis dan lebih sensitif dengan personal space-nya. Maka dari itu Open Architecture tidak dapat dilihat dari masalah arsitekturnya saja tetapi masalah sosial yang ada pada kota-kota tersebut. Terdapat aspek-aspek yang mengarah kepada Open Architecture yaitu Open Society dan Open City (Oldenburg, 1989).

Open Society dan Open City merupakan sekelompok masyarakat yang memiliki toleransi dan keterbukaan, Open City merupakan jawaban dari Open Society dalam bentuk fisik ruang dengan membangun sebuah kota secara bersama-sama dengan menggunakan Open System (sistem yang terbuka secara sosial). Open System mendukung dan merangkul karakter kota menjadi adaptif dan eksperimental (Picon, 2015).

Open Architecture sendiri juga didasarkan pada penyambutan dari sepemikiran atau berbagai pemikiran lain yang jelas ke dalam proses desain arsitektur. Open Architecture juga dikaitkan dengan, misalnya fleksibilitas dan kemampuan beradaptasi bentuk, kolektivitas dan kolaborasi, multisiplisitas makna, demokrasi dan pluralitas, desain yang terbuka, perluasan hak asasi manusia dan kewarganegaraan sosial, dan solidaritas transnasional (Oldenburg, 1989).

\section{The Third place}

Open Architecture merupakan The Third place bagi masyarakat kota. The Third place adalah sebuah program yang akan membantu masyarakat kota agar bersifat humanis, openness, dan dinamis. Membantu masayarakat untuk memahami kota sebagai entitas bersama dengan layanan publik bersama, sumber daya infrastruktur bersama, dan ruang bersama. Kemunculan Third place sendiri disebabkan dari faktor revolusi Industri, dimana tempat bekerja dan tempat tinggal berada di tempat yang berbeda (Oldenburg, 1989).

Letak pemukiman dibuat terpisah jauh dari pusat kota, sehingga memaksa pergerakan mobilitas yang tinggi. Lingkungan yang dahulu memiliki tempat untuk bersosialisasi di tengah pemukiman seperti kafe atau bar menghilang keberadaanya. Hal ini membuat individu didalamnya hanya memiliki kesempatan kecil untuk merasa saling terkait dalam sebuah hubungan sosial dengan sekitarnya. The Third place menurut Ray Oldenburg memiliki kriteriakriteria sebagai berikut (Oldenburg, 1989):

1) Mereka Neutral (tidak membedakan)

Setiap individu dapat datang dan pergi sesuai keinginannya, mereka tidak terikat pada third place secara finansial, politik, hokum, atau lainnya.

2) Kesejajaran dalam bermasyarakat (Leveler)

Third place tidak mementingkan status ekonomi atau sosial seseorang dalam suatu masyarakat. Tidak ada syarat atau hirearki sosial untuk berpartisipasi di dalam Third place.

3) Komunikasi menjadi hal penting dalam aktivitasnya

Percakapan yang menyenangkan adalah focus utama dari kegiatan Third place.

4) Mudah di akses dan mudah mengakomodasi

Third place harus terbuka, mudah diakses, dan akomodatif (memenuhi kebutuhan).

5) Mempunyai regulasi

Third place memiliki pengunjung tetap, hal ini memberikan atmosfir dalam ruang dan membantu interaksi sosial.

6) Third places secara fisik sederhana dan bersahaja

Bentuk Third place terlihat sederhana, untuk menguatkan kesan kesetaraan bagi pengunjung yang datang dengan penampilan apa adanya.

7) Memiliki suasana yang Playful (menyenangkan)

Percakapan di dalam Third place bersifat menyenangkan, canda dan tawa lebih umum terdengar menjadi daya tarik Third place di lingkungan sosial. 
8) A Home Away From Home

Pengunjung memiliki rasa nyaman dan hangat tanpa adanya kepemilikan bangunan pada Third place.

\section{a) Wadah}

Berdasarkan Kamus besar Bahasa Indonesia (KBBI), arti kata wadah berarti kiasan tempat berkumpulatau berhimpun.

\section{b) Ruang Interaksi}

Berdasarkan Kamus Besar Bahasa Indonesia (KBBI), makna kata Interaksi antar ruang menggambarkan suatu cara mengelola ruang-ruang berlandaskan kemampuan serta permasalahannya dan keterkaitan antara suatu ruang dengan ruang-ruang yang terdapat disekitarnya. Keterkaitan antar letak ataupun ruang dapat dilihat secara fisik ataupun non fisik.

\section{c) Ruang Pelarian}

Ruang melarikan diri, juga dikenal sebagai permainan melarikan diri, adalah permainan di mana tim pemain bersama-sama menemukan petunjuk, menyelesaikan teka-teki, dan menyelesaikan tugas di satu kamar atau lebih untuk maju dan mencapai tujuan tertentu dalam waktu terbatas. Tujuannya adalah sering melarikan diri dari situs permainan

\section{d) Pameran \& Galeri}

Menurut Kamus Besar Bahasa Indonesia (KBBI), Nomina pameran berarti pertunjukan (hasil karya seni, barang hasil produksi, dan sebagainya).

\section{e) Sejarah Ruang Pelarian (Escape Room)}

Konsep asli Escape Games berasal dari video game yang disebut 'Escape Rooms' atau 'Escape Games'. Pemain dari permainan itu harus menyelesaikan misteri dengan berinteraksi dengan karakter di sekitar mereka untuk melarikan diri dari ruangan dan pindah ke tingkat berikutnya. Gim video Escape Game pertama, Crimson Room, dibuat pada 2004 oleh Toshimitsu Takagi. Ini menciptakan istilah yang digunakan Takagim untuk menyebut jenis permainan ini. (wikipedia)

Perusahaan Jepang SCRAP pertama kali mengubah konsep pada tahun 2007 menjadi Ruang Escape Langsung. Pendirinya, Takao Kato, ingin agar pemain tenggelam dalam permainan. Pemain secara fisik akan bermain di ruang bertema dan memecahkan misteri untuk melarikan diri dalam waktu yang ditentukan. Escape Games mulai muncul di seluruh Asia sebelum tiba di Eropa. Di Cina, klub 'Beijing Takagism' didirikan pada 2012.

Budapest, di Hongaria, adalah kota perintis untuk Game Escape Langsung di Eropa. Pada 2011, perusahaan Parapark diciptakan. Pendirinya, Attila Gyurkovics, memiliki ide untuk membuka Live Escape Game tanpa mengetahui bahwa mereka sudah berkembang dengan baik di Asia. Attila punya ide sambil mengerjakan ide-ide untuk proyek Tim Building baru. Setahun kemudian, asal mula permainan melarikan diri berlanjut dengan pembukaan waralaba pertama di Hongaria: Hint Hunt. Pada tahun yang sama perusahaan SCRAP diciptakan di Amerika Serikat dengan nama "Real Escape Game". Petunjuk Berburu cepat mengekspor konsep ke Inggris, dan kemudian Prancis pada 2013. 2013 juga merupakan awal dari kisah Escape Game di Kanada.

\section{f) Jenis - jenis Escape Room \\ - Linear escape room \\ - Escape Room Non-linear \\ - Kamar Escape Linear dan Non-Linear \\ - Scavenger Hunt \\ - Red Herring}




\section{METODE}

\section{Arsitektur Mimesis}

Mimesis (dari kata "mime") merupakan suatu proses peniruan. Mimesis terdapat di dalam diri setiap manusia sehingga proses peniruan ini pula jadi proses terciptanya budaya. Secara sistematis, Mimesis berlangsung karena kita menjadikan orang lain selaku model. Mimesis pada awal mulanya berasal dari zaman Yunani kuno, kala mereka mau mengkarakterisasikan dasardasar alamiah dari lukisan serta pahatan, puisi dan musik, tarian serta teater yang pada era modern disebut seni. Sebagian dari mereka yang hidup pada era itu menyebutnya dengan sebutan mimemata (asal kata: mimema) yang pada akhirnya menciptakan suatu karya yang diucap mimesis. Sebagian kata dalam bahasa Yunani kuno kerap dihubung-hubungkan dengan mimesis, antara lain mimema (imitasi), eikon (image) serta homoioma (mempersamakan) yang memperkenalkan sesuatu penafsiran yang lebih luas lagi tentang mimesis. Kelainan sangat mendasar dari teori mimesis adalah terletak pada mimena dan perihal yang nyata/asli. Misalnya sebuah rumah merupakan hal yang nyata sebaliknya lukisan maupun pahatan yang menyerupai suatu rumah ialah suatu mimena, suatu yang serupa rumah tetapi bukan suatu rumah. Mimesis salah satu alternatif dalam yang dipergunakan dalam perancangan yang memperkenalkan kembali rupa awal dengan mengaplikasikan perubahan-perubahan yang memperkenalkan suatu karya yang bersifat ganda. Dari segi "aspek konservatif apresiasi estetika" arsitektur mimesis seakan-akan lebih miskin daripada seni-seni lainnya (D.J.Pasla, 2016).

\section{Hybrid Architecture}

Hybrid Architecture adalah penggabungan sekian banyak aspek yang berbeda dalam ruang lingkup arsitektural. Hybrid adalah hasil persilangan alias penggabungan dari suatu yang berbeda. Penekanan penafsiran hybrid ini merupakan" hasil" dari persilangan maupun penggabungan. (Febriana D.S. Rompis dan Sangkertadi, 2011)

Menurut Jencks, hybrid ialah sesuatu metode untuk menghasilkan suatu dengan pola-pola lama( sejarah), akan tetapi dengan bahan serta tata cara yang baru (D.J.Pasla, 2016). Dengan kata lain mengkombinasikan bentuk-bentuk tradisional dengan teknik modern. Prosedur hybrid merupakan tahapan-tahapan quatation, manipulasi elemen, serta unifikasi dan penggabungan. Tata cara ini mempunyai kesamaan dengan versi Ventury, yaitu meliputi tatanan, fragmentasi, infeksi serta superimposisi (Ikhwanuddin, 2005). Ada pula tahapan dari prosedur Hybrid ini merupakan sebagai berikut:

\section{- Elektik atau Quotation}

Artinya menelusuri dan memilih pembendaharaan dari bentuk dan elemen arsitektur dari masa lalu yang diangkat kembali karena dianggap masih potensial. Asumsi dasarnya yaitu telah mapannya kode dan makna yang dapat diterima dan dipahami oleh masyarakat.

- Manipulasi dan Reduksi

Elemen-elemen elektik ataupun hasil dari quotation tersebut berikutnya dimanipulasi atau dimodifikasi dengan cara-cara yang dapat menggeser, mengganti, dan ataupun memutarbalikan arti yang sudah ada. Sebagian teknik manipulasi ini terdiri dari:

- Reduksi dan siplikasi

- Repetisi

- Distorsi bentuk

- Disorientasi

- Disproporsi

- Dislokasi

Hasil akhir desain yang telah ditetapkan urutannya adalah berdasarkan dari penggabungan dan penyatuan elemen yang telah di manipulasi dan di modifikasi. 


\section{DISKUSI DAN HASIL}

Pemilihan lokasi dilakukan berdasarkan kesesuaian terhadap kriteria Third place yang ditentukan dengan melakukan analisis yang terbagi dalam 4 tahap utama, yaitu mendalami konteks dan isu pada tapak yang berupa kekurangannya ruang interaksi dan juga semakin menurunnya salah satu ciri khas pada tapak yang merupakan barang antik, melakukan analisis dalam skala perkotaan, analisis secara makro dan mikro, lalu menerapkan analisis analisis tersebut melalui observasi lingkungan dan melakukan wawancara terhadap masyarakat sekitar. Analisis perkotaan dilakukan dengan mengamati potensi tapak dan urban life dari kawasan tersebut dan diperpadukan dengan aturan aturan desain perkotaan seperti mengamati dimana axis, skyline, vista, nodes dan flow pejalan kaki, dan menerapkannya pada flow tapak, sehingga calon penggunadapat merasakan kenyamanan ketika mengunjungi tapak. Analisis secara makro dilakukan dengan mapping secara utuh, sedangkan analisa secara mikro dilakukan dengan memperhatikan kondisi tapak, peruntukan tapak, dan aksesbilitas tapak (lihat gambar 1).

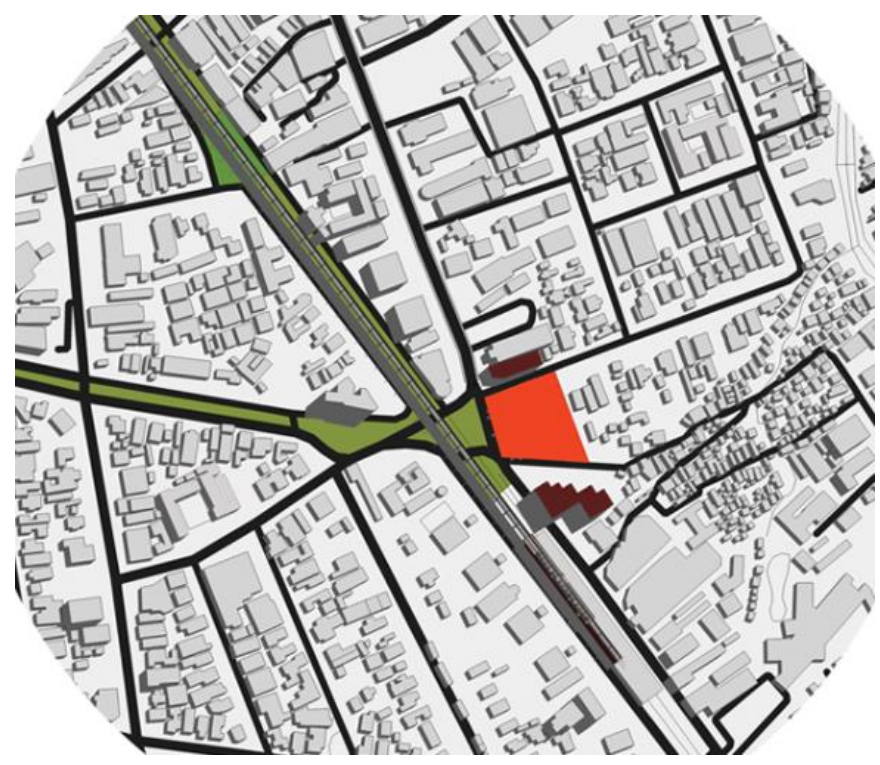

Gambar 1. Tapak terpilih

Sumber: Penulis, 2019

Pada sekitar tapak terdapat isu kekurangan interaksi sehingga pada penduduk, pekerja, dan masyarakat sekitar mempunyai kubu yang kurang mengintolerir dan bertoleransiantar satu sama lain. Menteng, kawasan terpilih mempunyai konteks seni, barang antik yang kian pudar hingga ciri khas tersebut tidak lagi menjadi suatu ketertarikan bagi masyarakat sekitar yang menghasilkan gap antara ciri khas dan juga masyarakat. Dengan konteks tersebut, merupakan akar akar dan panutan bagi ruang ketiga bagi masyarakat terbangun sehingga dapat terlahir kembali ciri khas tersebut.

Analisis perkotaan menjadi pedoman perancangan proyek agar mendapatkan sebuah visi dan misi yang menonjol dan dapat mendukung perkembangan kota terutama dalam skala kecamatan. Selain itu, dengan memaksimalkan penerapan analisis perkotaan, para pengguna pun akan terasa lebih nyaman ketika mengunjungi tempat ini karena sudah menyesuaikan dengan peraturan setempak, penanganan dan perencanana yang optimal sehingga apabila adanya perkembangan dan perubahan pada tapak, bangunan yang dikunjungi tetap menjadi sebuah ikon dan menjadi sebuah tempat dimana masyarakat hargai di karenakan exclusiveness yang mereka dapat ketika mengunjungi tempat ini.

Dalam perancangan konsep bangunan ini, dalam menjawab dan menangani isu yang terdapat pada tapak yang berupa kekurangannya ruang interaksi, maka dari itu, Wadah Pertukaran Pengalaman Ruang ini di rancang dengan banyaknya ruang ruang yang dapat 
meningkatkan interaksi antar pengunjung, yang tidak mengenal usia, kalangan, status sosial dan kedudukan, sehingga dapat melahirkan suatu kebiasaan masyarakat yang baru dan inovatif. Dasar dari konsep perancangan ini pula menerapkan elemen elemen yang ditarik dari konteks di sekitar yang merupakan barang antik, dengant ujuan menghidupkan kembali ciri khas tersebut yang kian lama makin pudar. Barang antik tersebut dikaitkan dengan sesuatu yang sudah runtuh karena semakin dimakan waktu, ia makin tidak dikenal oleh masyarakat sekitar, sehingga dengan menerapkan reruntuhan pada fasad, program banguna dan flow pengguna, di harapkan dapat meningkatkan kembali keindahan dan keunikan dari barang antik tersebut, yang juga di tunjang dengan area area komersil yang mendukung kegiatan jual beli barang antik tersebut (lihat gambar 2).

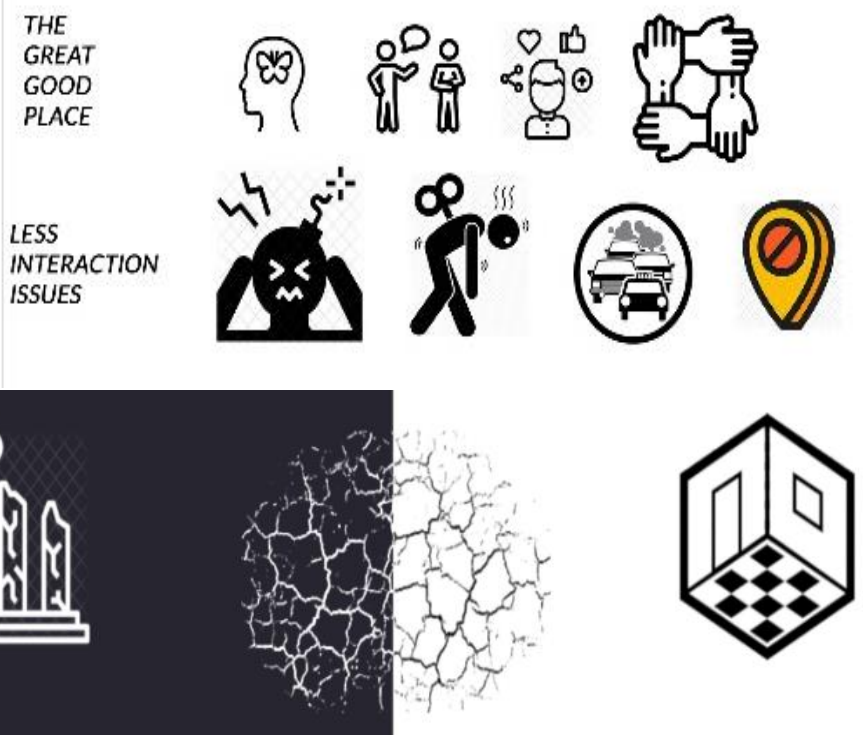

Gambar 2. Konsep perancangan

Sumber: Penulis, 2019

Perancangan ruang ruang pada proyek ini di desain semaksimal mungkin untuk meningkatkan interaksi, sehingga terbentuklah sebuah narasi bagi para pengguna, yang terbentuk dari pergerakan zaman yang kian berkembang. Dalam perancangan ruang pada proyek ini, dibuat dengan tema ruang yang berbeda, sehingga memberikan suatu pengalaman ruang yang baru pada calon pengunjung, yang menghasilkan interaksi dan inovasi (lihat gambar 3 dan 4).

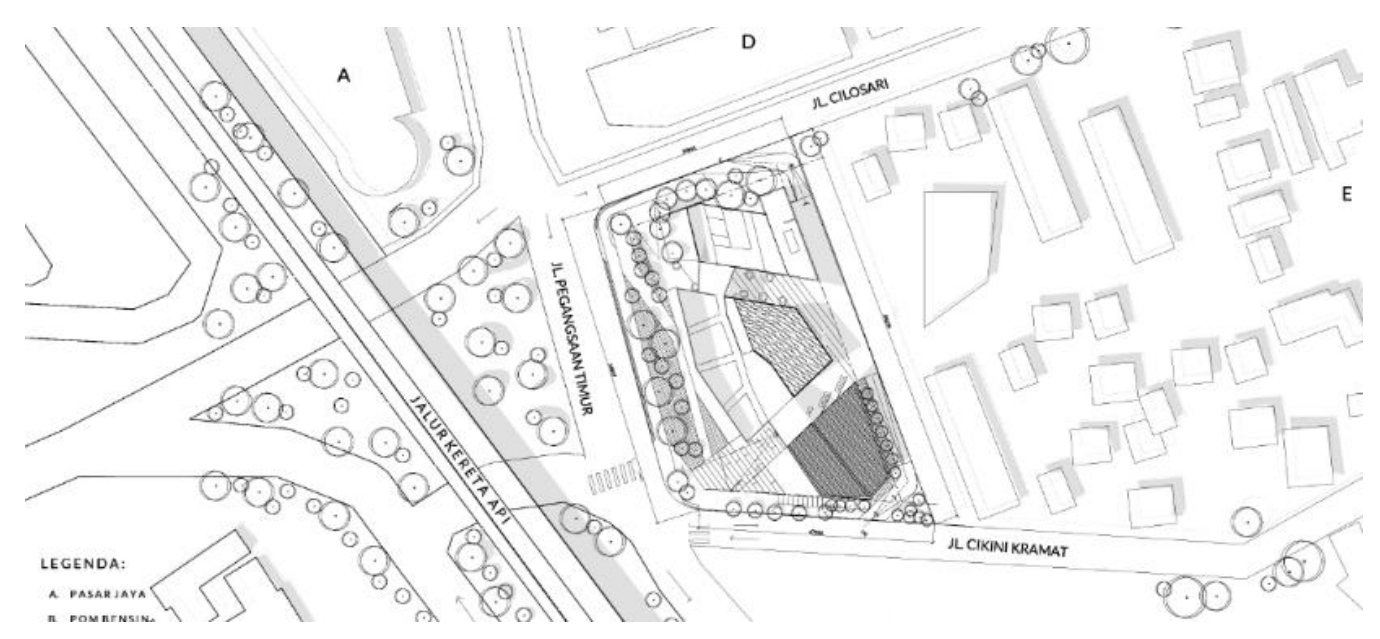

Gambar 3. Blok Plan Bangunan

Sumber: Penulis, 2019 


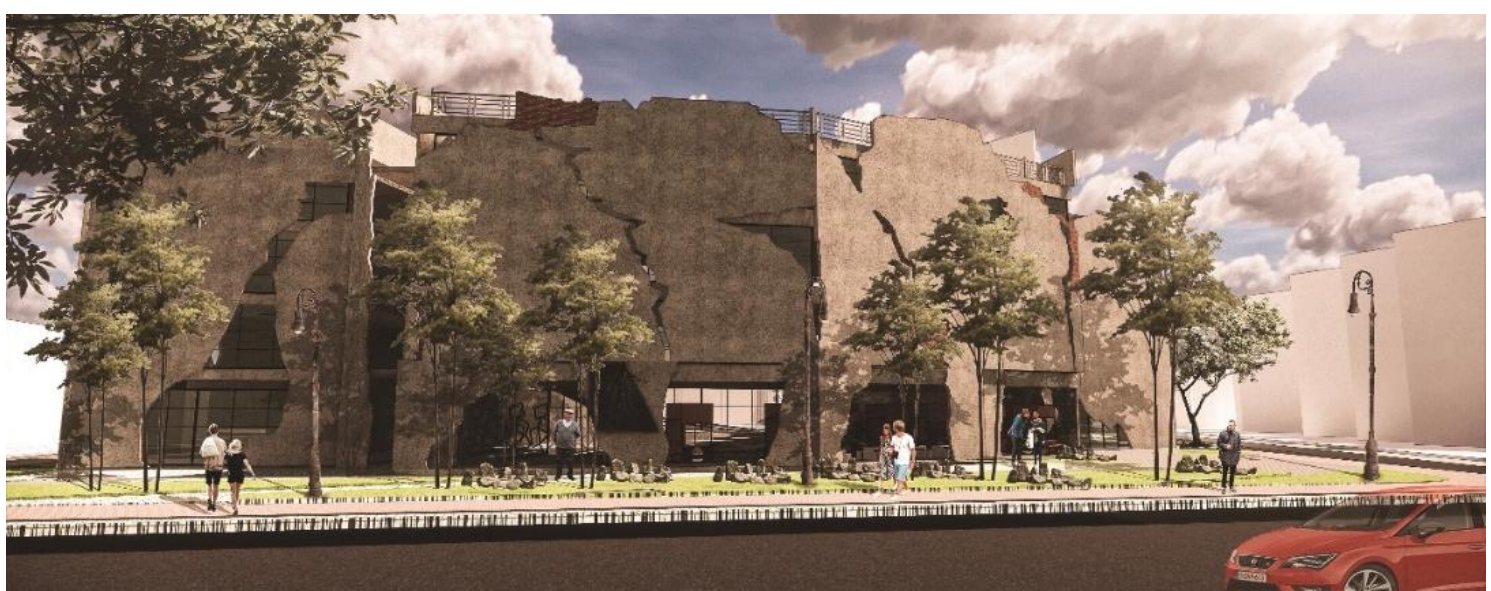

Gambar 4. Perspektif

Sumber: Penulis, 2019

Sebagaimana yang tertulis di atas, bahwa penerapan dan pendekatan pada konteks barang antik yang dikaitkan dengan reruntuhan, membuat bangunan yang dirancang menjadi sesuatu yang berbeda dengan bangunan bangunan sekitar (lihat gambar 4). Penerapan elemen retak pada bangunan juga membuatnya menjadi interaktif ketika dimalam hari yang memberikan kesan misterius dari dalam bangunan yang mempunyai cahaya yang keluar dari celah celah retak tersebut. Selain itu, bangunan dirancang senyaman mungkin dengan adanya cross ventilation dan penggunaan material sustainable (lihat gambar 5).

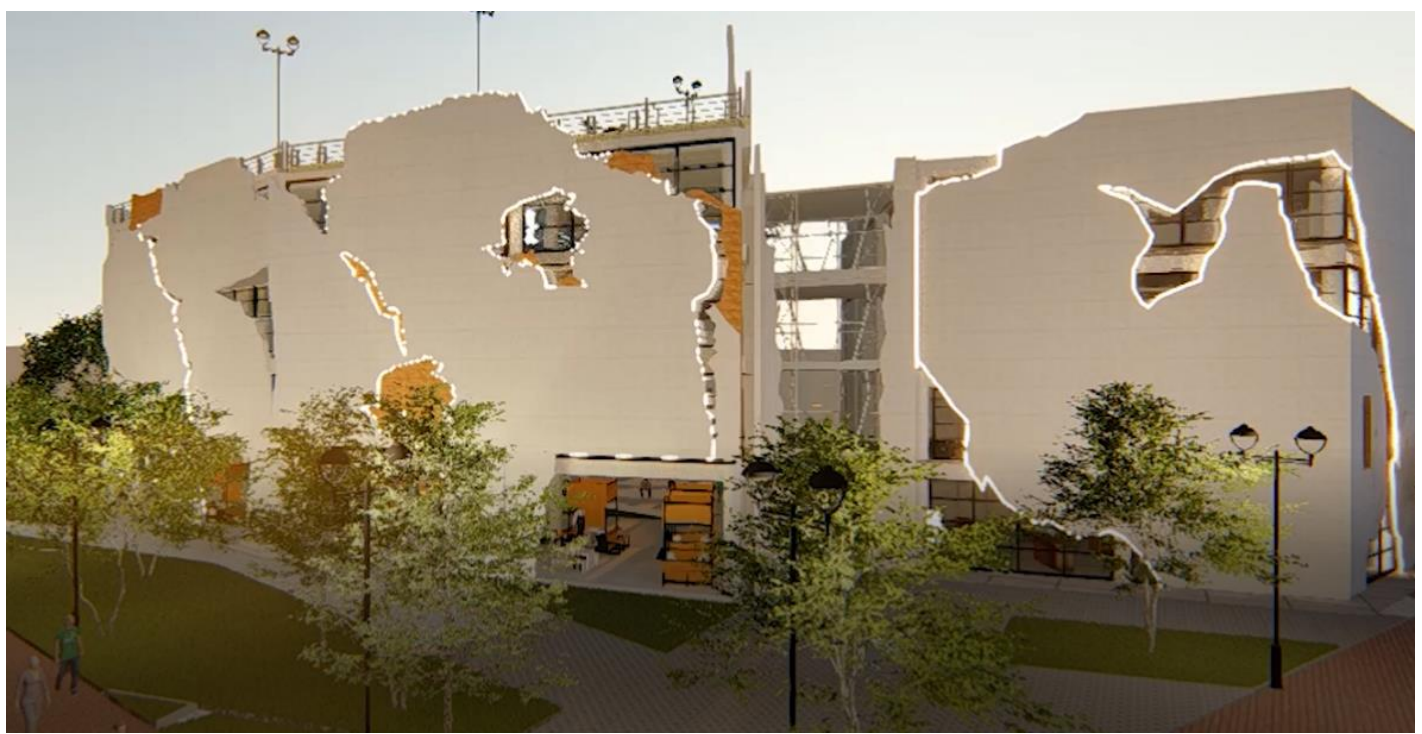

Gambar 5. Perspektif

Sumber: Penulis, 2019

\section{KESIMPULAN DAN SARAN}

Perancangan Wadah Pengalaman Ruang di Menteng, didesain dengan menciptakan atau mengkombinasikan tipologi baru yang diadaptasi dengan kebiasaan atau pendekatan kepada masyarakat Menteng. Kehadiran ini dibuat untuk mewadahi masyarakat akan kekurangan sosialisasi dan interaksi sehingga dapat menghasilkan sesuatu yang bermanfaat yang berdampak bagi ligkungan dan masyarakat sekitar. Dengan memerhatikan SDGs, bangunan ini mengikuti kriteria atau acuan yang mengarahkan perancangannya pada pembangunan yang berkelanjutan. 
Penerapan arsitektur mimesis dan behaviorial dan mengimplementasikan tekik tersebut pada kebutuhan dan pengalaman ruang pada proyek ini, menjadi titik utama keberhasilan bangunan. Dalam menggaet masyarakat kecamatan menteng yang mayoritas merupakan pekerja dan pelajar selanjutnya yang jauh lebih modern untuk berkunjung; proyek ini banyak memakai instrumen-instrumen digital yang menyajikan keunikan dari asal usul tempat yang mengajak pengunjung yang berkunjung memiliki pengalaman yang interaktif dengan wahana dan entertainment ruang pelarian sebagai fungsi utama bangunan yang diperpadukan dengan objek yang di pamerkan di dalamnya.

Penetuan lokasi tapak dan lingkungan sekitar juga memperhitungkan intensitas banyaknya pengunjung yang datang. Namun dalam proses pengajuan proposal dan pengembangan desain proyek ini masih membutuhkan saran saran serta kritikan daripada dosen penguji, sehingga desain yang di keluarkan tidak lari dari koridor desain yang telah di tetapkan.

\section{REFERENSI}

Anthony, A. C. (2003). Poetics Of Architecture. New York: Van Nostrand Reinhold.

Arsitektur dan Seni. (2013). Jurnal Sains Dan Seni Pomits, Vol. 2, 2337-3520.

Broadbent, G. (1980). Design in Architecture. California: Hilde Publishing.

David A., Karp, W. C. (1976). Sociology in everyday life. California: F E Peacock Publishers, Inc.

Florida, R. (2012). The Rise Of The Creative Class (Vol. 34). California: Basic Books. doi:36285l/f85969

Oldenburg, R. (1989). the Great Good Place. NewYork: Da Capo Press.

Pasla, D.J. V. (2016). Arsitektur Mimesis. Arsitektur Mimesis, 47-55.

Picon, A. (2015). Smart Cities : A Spatialized Intelligence. Michigan: Wiley Ann Harbor. 
